\title{
試合期の韓国プロサッカー選手の二重標識水法による 総エネルギー消費量測定
}

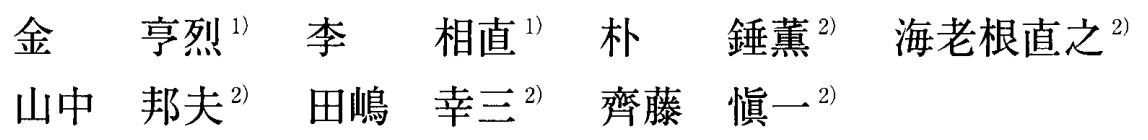

\section{Measurement of total energy expenditure by the doubly labeled water method during a competitive season in Korea professional football league players}

\author{
Hyung-Ryul Kim ${ }^{1}$, Sang-Jik Lee ${ }^{1}$, Jong Hoon Park ${ }^{2}$, Naoyuki Ebine ${ }^{2}$, Kunio Yamanaka ${ }^{2}$, \\ Kouzou Tashima ${ }^{2}$ and Shinichi Saitoh ${ }^{2}$
}

\begin{abstract}
To determine the daily energy requirements of soccer players, we measured total energy expenditure (TEE) in nine Korean Professional Football League players (mean \pm SD; age $29 \pm 4$ years, height $180 \pm 7 \mathrm{~cm}$, body mass $75.7 \pm 10.3 \mathrm{~kg}$ ) during 7 days of a competitive season using the doubly labeled water (DLW) method. Energy intake (EI) was simultaneously estimated from 7 days of dietary records. Mean TEE and EI were $16.8 \pm 2.4 \mathrm{MJ} /$ day $(4,013 \pm 583 \mathrm{kcal} /$ day $)$ and $16.4 \pm 1.6$ $\mathrm{MJ} /$ day $(3,941 \pm 382 \mathrm{kcal} /$ day $)$, respectively. EI was highly correlated with TEE $(\mathrm{r}=0.747, \mathrm{p}<0.05)$ and was also no significant difference. The physical activity level (PAL = TEE/estimated basal metabolic rate) was $2.22 \pm 0.28$. We discussed the energy requirements of soccer players during a competitive season based on PAL of both Korean and Japanese Professional Football League players.
\end{abstract}

Key words : professional sport, energy requirement, DLW method, energy intake, physical activity level

(Japan J. Phys. Educ. Hith. Sport Sci. 48: 717-723, November, 2003)

1）威德大学社会体育学科

厂 780-713 慶北慶州市江東面有琴里山 50, 韓国

2) 筑波大学体育科学系

T 305-8574 茨城県つくば市天王台 1-1-1

連絡先 齊藤壃一
1. Division of Health and Sports Sciences, University of Uiduk San 50, Yukumri, Gangdong, Gyeongju, Korea 780-713

2. Institute of Health and Sport Sciences, University of Tsukuba 1-1-1 Tennohdai, Tsukuba, Ibaraki 3058574

Correspondingauthor_ssp@taiiku.tsukuba.ac.jp 
キーワード：プロスポーツ，エネルギー必要量， DLW法, エネルギー摂取量, 生活 活動指数

\section{はじめに}

スポーツ選手のパフォーマンスにとって, 適切 なエネルギーや举養素の摂取は必要不可欠なもの であり，そのために栄養摂取ガイドラインがつく られている（齊藤・海老根，2002）。これに関連 して，競技スポーツのコーチや選手，そしてスポ ーツ科学者はスポーツ選手の総エネルギー消費量 (Total Energy Expenditure：TEE) に関心を持 ってきた，通常，個々人のエネルギー消費量は心 拍数法や加速度計法のような方法で測定される が，これらの測定はしばしばトレーニングや試合 のパフォーマンスの妨げとなるので，測定デー夕 には不合理な影響が混在することになる（齊藤ほ か，1999）。ところで，二重標識水（Doubly Labeled Water：DLW）法は身体活動を制約する ことなく，ヒトの1日のエネルギー消費量を正確 に測定することができるフィールド研究のゴール ドスタンダードである。したがって，フリーリビ ングでのスポーツ選手の TEE 測定法として，エ ネルギー所要量（Recommended Energy Allowance：REA）を決定するためにこれまで 幅広く用いられてきた。しかし，このような研究 はトレーニング期の長距離選手や水泳選手に偏っ ており（Ebine et al.，2000），サッカー選手を対 象として，1日のエネルギー消費量をDLW 法で 測定した例はJapan Professional Football League （J. League）選手を対象としたEbine et al. (2002) の報告のみである。本研究の目的は，DLW 法を 用いて，試合期の 1 週間にわたり，Korea Professional Football League（K. League）選手の TEE を測定し，サッカー選手の REA を検討すること である. 加えて, 食事記録によるエネルギー攝 取量（Energy Intake：EI）が DLW 法による TEEとどれぐらい一致しているかについても検 討した.

\section{I 実験方法}

\section{1. 被験者}

K. League に所属する某プロサッカーチームの レギュラー選手 9 名を被験者とした。この内の 2 名はFIFA 2002 年韓国／日本ワールドカップ出 場選手であった。すべての被験者は糖尿病やその 他の代謝疾患の既往歴がなかった。測定開始に先 立ち, 被験者及び監督，コーチには測定内容と目 的について十分な説明を実施し，参加の同意を得 た。被験者の年齢，身長，体重，体脂肪率はそれ ぞれ $29 \pm 4$ 歳, $180 \pm 7 \mathrm{~cm}, 75.7 \pm 10.3 \mathrm{~kg}$, $11.3 \pm 2.9 \%$ (mean $\pm \mathrm{SD})$ であった.

\section{2. 実験概要}

実験のプロトコールを Fig. 1に示した。実験期 間は，2002年度 K. League 春のシーズンの本戦中 7 日間であった。この実験期間中，チームとして の総練習時間は 700 分，試合は 1 日（水曜日）で あった。被験者には実験期間中，普段どおりのト レーニングと食事習慣を維持し，体重の意識的な 減量と増量は行わないように指示した。

\section{3. 総エネルギー消費量の測定}

1) 二重標識水 $\left({ }^{2} \mathrm{H}_{2}{ }^{18} \mathrm{O}\right)$ の投与方法

標識水の投与に先立ち，ベースラインとなる尿 の採取を行った（Fig.1）。Day0の早朝，我々の 方法（Ebine et al.，2000）を参考に，総体水分量 (Total body water：TBW) を体重の 60\%と仮 定し, 重水素 $\left({ }^{2} \mathrm{H}\right)$ を $0.12 \mathrm{~g}^{2} \mathrm{H}_{2} \mathrm{O} / \mathrm{kg}$ estimated TBW (99.8atom \%) の割合で， ${ }^{18} \mathrm{O}$ を $2.5 \mathrm{~g}$ $\mathrm{H}_{2}{ }^{18} \mathrm{O} / \mathrm{kg}$ estimated TBW (10.0 atom\%) の割合 で経口投与した。

2）総体水分量および除脂肪組織量の算出方法

標識水投与から 3 時間後と 4 時間後に尿サンプ ルを採取し，重水素の希釈容積の平均值から，総 体水分量と除脂肪組織量を以下の式により算出し た。

DSh $(\mathrm{mol})=[\mathrm{W} \cdot \mathrm{A} \cdot(\mathrm{Ea}-\mathrm{Et})] /$

$$
[18.02 \cdot \mathrm{a} \cdot(\mathrm{Es}-\mathrm{Ep})]
$$




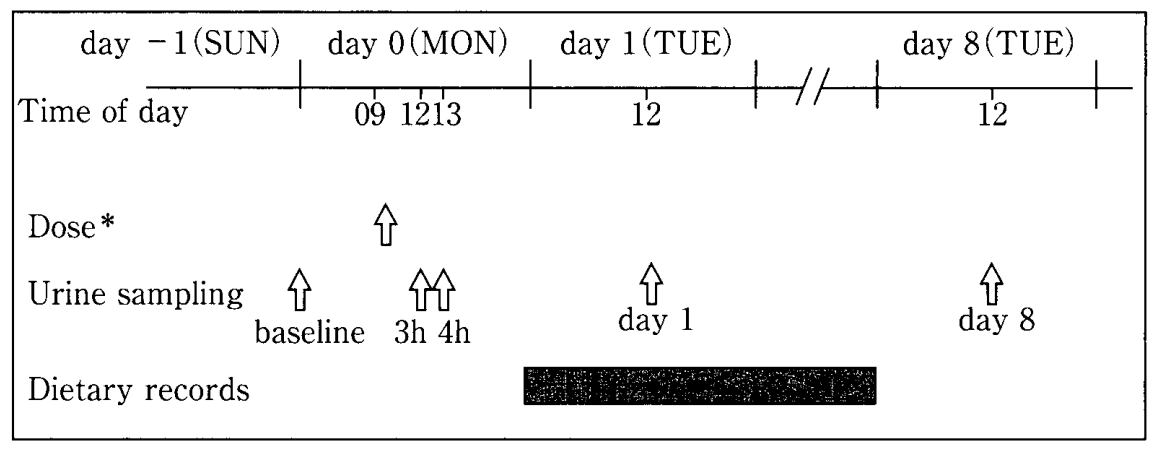

* ${ }^{2} \mathrm{H}_{2} \mathrm{O}: 0.12 \mathrm{~g} / \mathrm{kg}$ estimated TBW (99.8 atom \%)

$\mathrm{H}_{2}{ }^{18} \mathrm{O}: 2.5 \mathrm{~g} / \mathrm{kg}$ estimated TBW (10.0 atom \%)

Fig. 1 Experimental design.

ただし，DShは ${ }^{2} \mathrm{H}$ の希釈容積 (mol)，Wは分 析の際にDLW 溶液を希釈するために用いた飲料 水の量 $(\mathrm{g}), \mathrm{A}$ は DLW 溶液の被験者への投与量 $(\mathrm{g}), \mathrm{Ea}$ は希釈した DLW 溶液の ${ }^{2} \mathrm{H} の \delta \%, \mathrm{Et}$ は分析の際にDLW 溶液を希釈するために用いた 飲料水の ${ }^{2} \mathrm{H} の \delta \%$, a は飲料水により希釈された DLW 溶液の量（g), Es は投与した DLW 溶液が 体水分で平衡となった時の体水分における ${ }^{2} \mathrm{H} の$ $\delta \%, \mathrm{Ep} は \mathrm{DLW}$ 溶液投与前の被験者の体水分 における ${ }^{2} \mathrm{H} の \delta \%$ である. 総体水分量は次の式 によって求めた。

TBW $(\mathrm{mol})=$ DSh $(\mathrm{mol}) / 1.041$

TBW $(\mathrm{kg})=$ DSh $(\mathrm{kg}) / 1.041$

ただし, DSh $(\mathrm{kg})=\mathrm{DSh}(\mathrm{mol}) \cdot 18.02 /$ 1000 である。除脂肪組織量 $(\mathrm{kg})$ は, 以下の式 により求め,これと体重から体脂肪率を計算した。

$\mathrm{FFM}=\mathrm{TBW} / 0.732$

3）総エネルギー消費量（TEE）の算出方法

本研究では, Two-point methodを用い, TEE の算出を行った。同位体の分析に必要なスポット 尿は, day1およびday8に採取した。これらのサ ンプルを用い， ${ }^{2} \mathrm{H}$ と ${ }^{18} \mathrm{O}$ の 1 日当たりの排出率を 求め, $\mathrm{CO}_{2}$ 産生率を次の式により算出した.

$\mathrm{rCO}_{2}=0.4556 \mathrm{TBW}\left(1.007 \mathrm{k}_{\mathrm{o}}-1.041 \mathrm{k}_{\mathrm{h}}\right)$

$\mathrm{rCO}_{2}: \mathrm{CO}_{2}$ 産生率 $(\mathrm{mol} / \mathrm{day})$

TBW : 総体水分量 $(\mathrm{mol})$

$\mathrm{k}_{0}:{ }^{18} \mathrm{O}$ の 1 日当たりの排出率

$\mathrm{k}_{\mathrm{h}}:{ }^{2} \mathrm{H}$ の 1 日当たりの排出率

TEEは, Respiratory Quotient $(\mathrm{RQ})=$ Food
Quotient（FQ）とすることで, Weirの間接熱量 測定の式を用いて $\mathrm{CO}_{2}$ 産生率から算出した。

$\mathrm{TEE}(\mathrm{kcal} / \mathrm{day})=22.4\left[3.9\left(\mathrm{rCO}_{2} / \mathrm{FQ}\right)+1.1\right.$ $\left.\left(\mathrm{rCO}_{2}\right)\right]$

なお， $\mathrm{RQ}$ FQで代用することによる䛊差は ほとんどないとされている（Black et al. 1986）。

4）試料の分析方法

サンプルの分析は，(株）日本酸素（東京）を 通じて ISO-Analytical Limited (UK) に依頼した。 サンプルの分析は，白金を5\%坦持させたアルミ ナ粒子を触媒に使用し，ANCA-GSLおよびGeo 20ー20 IRSM（ともにPDZ Europe Ltd., UK) によって，同位体分析を行った。分析はすべで; 3 回繰り返し行い, 平均值を各被験者の測定值と した。なお， 3 回繰り返し分析の標準偏差の平均 は， ${ }^{2} \mathrm{H} て ゙ ~ 1.23 \% ，{ }^{18} \mathrm{O}$ で $0.09 \%$ であった.

\section{4. エネルギー摄取量の測定}

実験期間の 7 日間ほぼ全員の被験者が所属チー ムの食堂で調整された食事を摂取した。そして， 摂取したすべての食品と飲料水をチームの栄養士 が記録した。食事記録の分析には，韓国食品成分 表第 6 次改定版を用いて行なった。エネルギー摂 取（EI）は一人ずつの食事摂取から測定し，7日 間の平均値として算出した。

\section{5. 基礎代謝量と食事摄取基準の推定}

基礎代謝量（BMR）は韓国人の栄養勧奨量第 7 次改定の基礎代謝量算出式を用いて以下のように 
算出した。

$\operatorname{BMR}(\mathrm{kcal} /$ day $)=66.473+13.751 \cdot \mathrm{W}+$

$$
\begin{aligned}
& 5.0033 \cdot \mathrm{H}-6.755 \cdot \text { Age } \\
& (\mathrm{yrs})
\end{aligned}
$$

ここで，W と H は体重 $(\mathrm{kg})$ と身長 $(\mathrm{cm})$ で ある。また，REA は以下のように算出した。

$\mathrm{REA}(\mathrm{kcal} /$ day $)=\mathrm{BMR} \cdot \mathrm{x}$

ここで, $\mathrm{x}$ は生活活動強度の指数であり, 我々 の被験者には, 強度 4 の指数 1.75 を用いた ${ }^{\text {(1). }}$

\section{6. 統 計}

得られた結果は平均値士標準偏差で示した。 TEEとEI，あるいはREA との比較には，対応の ある $\mathrm{t}$ 検定を用いた，TEEとEIの関係を求める のにはPearsonの積率相関係数を用いた。また， これらの一致度については, Bland and Altman プロットを用いて検定を行った（Bland and Altman, 1986). K. League と J. Leagueの平均值の 差の検定には, Student'sのt-testを用いた。なお， 統計的有意水準はいずれの場合も $5 \%$ とした。

Table 1 Summary of energy expenditure and related measurements

\begin{tabular}{lcccccc}
\hline $\begin{array}{c}\text { Subject } \\
\text { (Position) }\end{array}$ & $\begin{array}{c}\text { TEE } \\
\text { (MJ/day) }\end{array}$ & $\begin{array}{c}\text { EI } \\
\text { (MJ/day) }\end{array}$ & $\begin{array}{c}\text { EI-TEE } \\
\text { (MJ/day) }\end{array}$ & $\begin{array}{c}\text { REA } \\
\text { (MJ/day })\end{array}$ & $\begin{array}{c}\text { BMR } \\
\text { (MJ/day) }\end{array}$ & PAL \\
\hline 1 (GK) & 16.6 & 17.5 & 0.90 & 15.5 & 8.88 & 1.87 \\
$2(\mathrm{DF})$ & 18.2 & 17.5 & -0.70 & 13.4 & 7.67 & 2.37 \\
3 (DF) & 19.6 & 17.5 & -2.10 & 14.0 & 8.01 & 2.45 \\
4 (DF) & 16.0 & 15.9 & -0.10 & 13.5 & 7.70 & 2.08 \\
$5(\mathrm{MF})$ & 12.5 & 12.8 & 0.30 & 11.6 & 6.64 & 1.88 \\
6 (MF) & 19.8 & 17.5 & -2.30 & 12.5 & 7.17 & 2.76 \\
7 (MF) & 15.6 & 17.5 & 1.90 & 12.5 & 7.15 & 2.18 \\
$8(\mathrm{FW})$ & 18.2 & 15.9 & -2.30 & 12.0 & 8.07 & 2.26 \\
$9(\mathrm{FW})$ & 14.4 & 15.9 & 1.50 & 12.0 & 6.86 & 2.10 \\
Mean & 16.8 & 16.4 & -0.32 & 13.0 & 7.57 & 2.22 \\
SD & 2.4 & 1.6 & 1.63 & 1.2 & 0.66 & 0.28 \\
\hline
\end{tabular}

$\mathrm{TEE}=$ Total Energy Expenditure, $\mathrm{EI}=$ Energy Intake, REA = Recommended Energy Allowance (ver. 7), $\mathrm{BMR}=$ Basal Metabolic Rate, $\mathrm{PAL}=$ Physical Activity Level
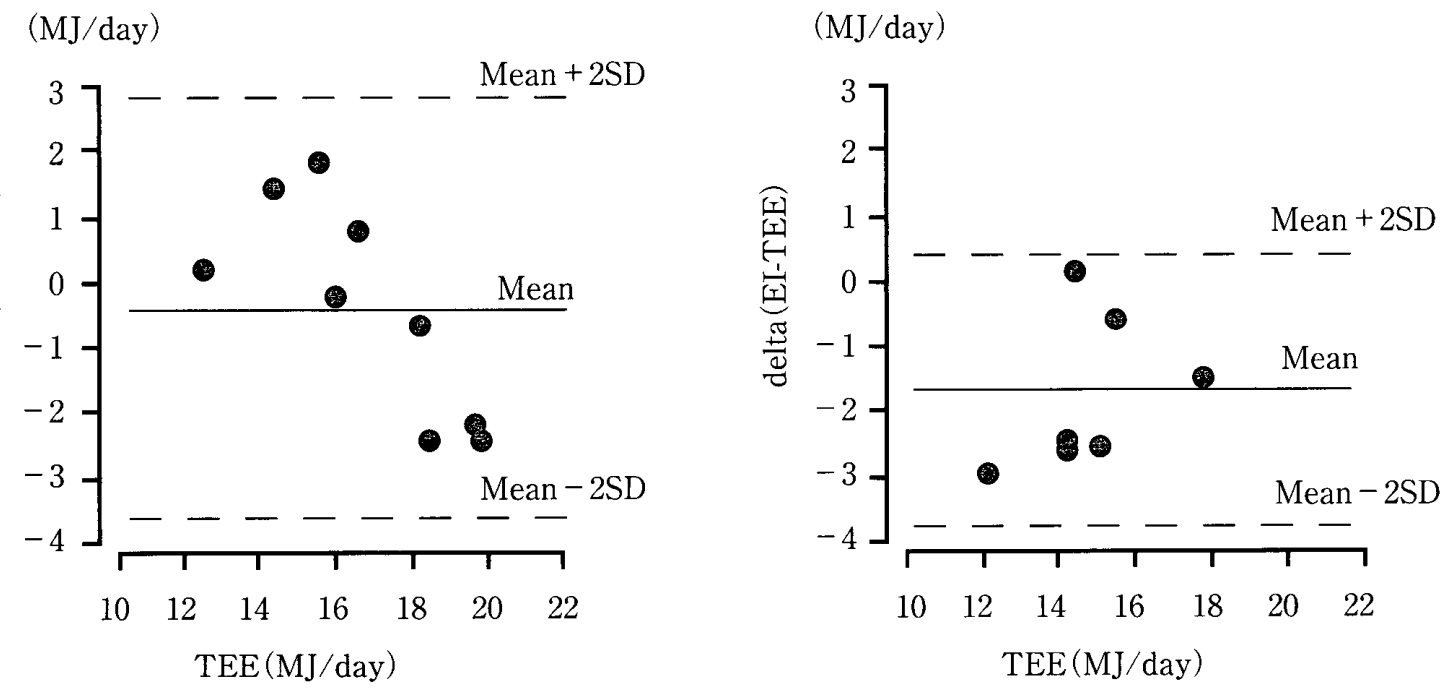

Fig. 2 Bland and Altman plots between TEE and EI-TEE in K. league (Left) and J. league (Right) (data from Ebine et al., 2002) professional soccer players. 


\section{II 結 果}

実験前後の体重 $(75.7 \pm 10.3$ vs. $75.2 \pm 10.2 \mathrm{~kg})$ には有意な差はなかった. Table 1 にTEE，EI などの結果を示した。 TEEと EIの平均值はそれ ぞれ $16.8 \pm 2.4 \mathrm{MJ} /$ day $(4,013 \pm 583 \mathrm{kcal} / \mathrm{day})$, $16.4 \pm 1.6 \mathrm{MJ} /$ day $(3,941 \pm 382 \mathrm{kcal} /$ day $)$ であり, TEEと EIの間に有意な差はなく, EIはTEEの 98.2\%であった。 また, Bland and Altman プロ ットによる $\mathrm{EI} の$ 推定值の妥当基準に対する正確 度（Accuracy）はー 1.0\%であり，信頼限界 (Limits of Agreement) は-3.59MJ/dayから $2.94 \mathrm{MJ} /$ day であり（Fig.2）, TEEと EI-TEEの 間には有意な相関関係があった $(\mathrm{r}=0.747, \mathrm{p}<$ 0.05). PAL, BMR， REAの平均值はそれぞれ $2.22 \pm 0.27,7.57 \pm 0.66 \mathrm{MJ} / \mathrm{day}(1,812 \pm$ $167 \mathrm{kcal} /$ day $), 13.0 \pm 1.2 \mathrm{MJ} /$ day $(3,170 \pm 292$ $\mathrm{kcal} / \mathrm{day}$ ）であり，REA とTEEの間には有意な 差があった $(\mathrm{p}<0.01)$.

\section{III 考察}

これまで，サッカー選手のEIについては，か なりの数の報告があるが, 試合期のサッカー選手 のエネルギー消費量についての報告はわずかであ る (Reilly and Thomas, 1979 ; Rico-Sanz et al., 1998). Ebine et al. (2002) はDLW 法により試 合期の日本プロサッカー選手のエネルギー消費量
を測定し， $14.8 \pm 1.70 \mathrm{MJ} / \mathrm{day}$ であると報告して いる．一方，試合期において週に 1 回もしくは 2 回の試合を行うイングランドリーグ1部に所属す るプロサッカー選手（人数 $=8$ 人，年齢 $22.6 \pm$ 3.2 歳, 体重 $73 \pm 7 \mathrm{~kg}$ ）の心拍数法を用いて測定 した TEEは $14.4 \mathrm{MJ} / \mathrm{day}$ と報告されている。これ らを総合すると，本研究で測定されたTEEは， プロサッカー選手の試合期のエネルギー消費量と して妥当な值であると考えられる。

韓国プロサッカー選手のPALの值（2.22 0.27）は，日本プロサッカー選手の試合期の值

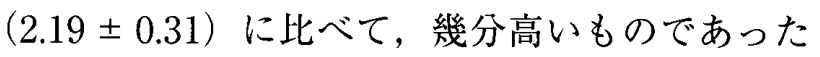
が, 有意な差ではなかった。一方, 最近我々が測 定した，プレシーズン合宿中の日本プロサッカー

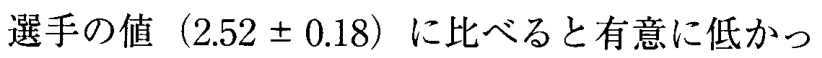
た（p<0.05）（齊藤ら，未発表デー夕)。したが って, 試合期のプロサッカー選手の PALは 2.2 前 後と考えて良いと思われる。これまで我々は，ス ポーツ選手のエネルギー所要量を導き出すための 生活活動指数として, 第五次改定の日本人の栄養

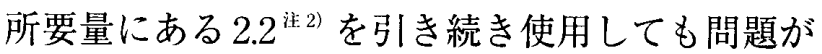
ないことを報告してきた（齊藤・海老根，2002）。 本研究は，このことをさらに確かめたものといえ よう。また，本研究でTEEとREAの間に有意な 差が認められたことから，韓国のスポーツ選手の エネルギー所要量を導き出すための生活活動指数

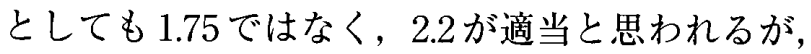
これについては今後韓国での検討がさらに必要で ある，ところで，ポジション別エネルギー消費量

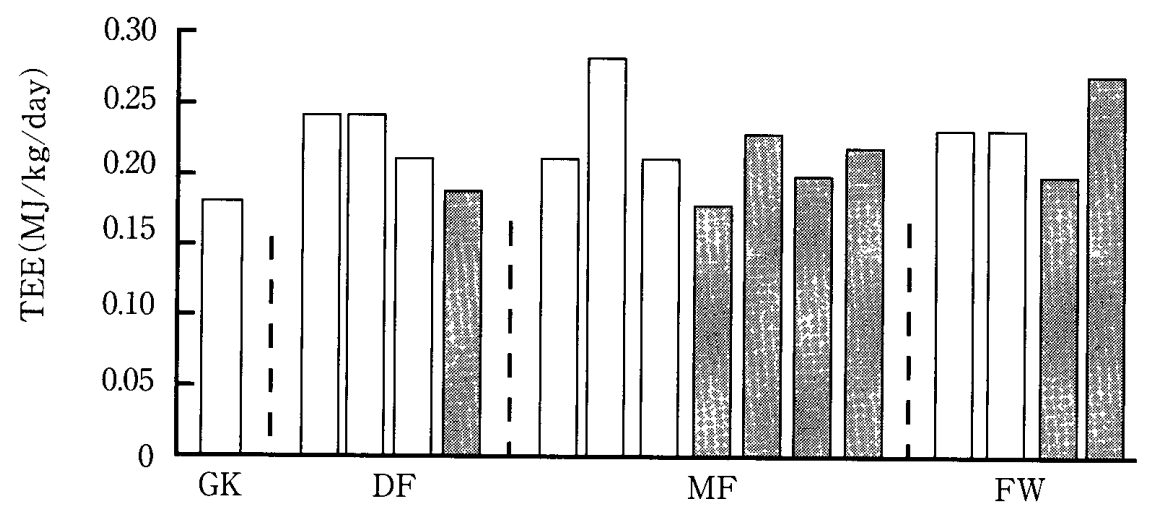

Fig. 3 Comparison of TEE between K. league (open bar) and J. league (dotted bar) (data from Ebine et al., 2002) professional soccer players. 
については, GK 1 名は $16.6 \mathrm{M} \mathrm{J} / \mathrm{d}$ a y $(3,983 \mathrm{kcal} / \mathrm{day}), \mathrm{DF} 3$ 名の平均は $18.0 \mathrm{MJ} / \mathrm{day}$ $(4,301 \mathrm{kcal} / \mathrm{day}), \mathrm{MF} 3$ 名の平均は $15.9 \mathrm{MJ} / \mathrm{day}$ $(3,812 \mathrm{kcal} / \mathrm{day}), \mathrm{FW} 2$ 名の平均は $16.3 \mathrm{MJ} / \mathrm{day}$ (3,899kcal/day) であった。一般に，サッカーで はMFの運動量が多いといわれている (Bangsbo, 1993）が，本研究ではそのような傾向はなく，体 重当たりの TEEを比べると, むしろ DFは MF より高い傾向にあった（Fig. 3)。面白いことには， 日本プロサッカー選手の場合には FW > MF> DFのような傾向を示したが，韓国プロサッカー 選手の場合には $\mathrm{DF}=\mathrm{MF}=\mathrm{FW}$ のような傾向に なったことである.この原因が, K. Leagueが週 に 1 回の試合, J. Leagueが週に 2 回の試合のよう にゲーム数の違いによるのか, チームの戦術の違 いによるのか，または全体練習中の運動量に違い があるために起こるのか，さらに個人練習の運動 量の違いによる影響のためなのか, については検 討できなかった。 $\mathrm{DF}, \mathrm{MF}, \mathrm{FW}$ 毎に， $\mathrm{K}$. League と J. Leagueの選手をあわせて，その体重 当たりの平均值を求めると $0.21 \mathrm{MJ} / \mathrm{kg} / \mathrm{day}$ $(51 \mathrm{kcal} / \mathrm{kg} / \mathrm{day}), 0.22 \mathrm{MJ} / \mathrm{kg} / \mathrm{day}(52 \mathrm{kcal} /$ $\mathrm{kg} /$ day $), 0.24 \mathrm{MJ} / \mathrm{kg} /$ day $(56 \mathrm{kcal} / \mathrm{kg} /$ day $)$ と なったが,これらの間には有意な差はなかった。 一方, GKの值 $(0.18 \mathrm{MJ} / \mathrm{kg} / \mathrm{day}, 43 \mathrm{kcal} /$ $\mathrm{kg} /$ day）は一番低かったが，それは子想された ことでもある。

本研究で求められた EI は TEEより $1.8 \%$ 低い 值を示しており，それらの間に有意な差はなかっ た。一方，スポーツ選手の EI と TEEの差異は良 く知られている（Westerterp et al., 1986 ; Schulz et al., 1992 ; Davies et al., 1997 ; Ebine et al., 2000). Ebine et al. (2002) の日本プロサ ッカー選手についての報告では，EIがTEEより 12\%低い值を示していた（Fig. 2).なぜ，本研 究でEI T TEEが一致したかについては, 測定し た 1 週間の大部分, 被験者全員がチームの食堂で 食事を取っていたためと推察された。これに関連 して，我々は先に実験室で調整した食事のみを摂 取させた大学院生の TEEと EIの間には高い相関 があること，また，Bland and Altman プロット
から検討すると, EI-TEEの平均值と標準偏差が 簡易エネルギー消費量測定である心拍数法や加速 度計法で求められたそれらよりも優れていること を報告した（海老根ほか，2002）。したがって， 本研究での栄養士による食事記録法により求めら れた EIは，サッカー選手のエネルギー必要量を 決める上での指標となるとも考えられる。しかし， 信頼限界については K. League と J. Leagueの間 にかなりの差があること（Fig. 2)，またEI-TEE のCV 值 $(-509.4 \%)$ は $\mathrm{EI}$ のそれ $(9.8 \%)$ に比 べてはるかに大きい（Table 1）ことから，食事 記録によるEIは集団の代表值としては適当であ っても，個人の值として用いるには十分ではない と思われる。

\section{IV とめ}

本研究では, サッカー選手の試合期における 1 日のエネルギー必要量を明らかにするために， DLW 法を用いて，韓国プロサッカー選手 9 名の TEEを測定した。その結果，以下のことが明ら かになった。

1. TEEは $16.8 \pm 2.4 \mathrm{MJ} /$ day であり, 第 7 次改 定韓国人の栄養勧奨量を用いて推定したREA

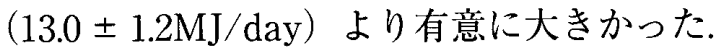

2. 韓国プロサッカー選手の PALは $2.22 \pm 0.28$ であり，先行研究で明らかにされた日本プロサッ

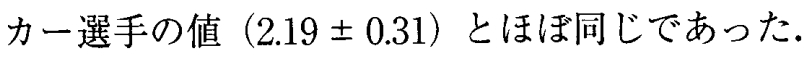
したがって，サッカー選手の試合期のエネルギー 所要量を PAL（生活活動指数）を用いて算出す る場合については，2.2を用いて推定してよいと 思われる。

3. EI $(16.4 \pm 1.6 \mathrm{MJ} /$ day $)$ と TEEはよく一致 しており,これは測定期間中の大部分, 被験者全 員がチームの食堂で食事を取っていたためと推察 された。

注

注 1）第 7 次改定韓国人の栄養勧奖量の生活活動強度 の指数 $\mathrm{x}$ は, 生活活動強度 1 では 1.2 , 強度 2 では 1.3 , 強度 3 では 1.5 , 強度 4 では 1.75 である. 
注2）エネルギー所要量（REA）は, 第六次改定日本 人の栄養所要量から, 基礎代謝量 (BMR) に生 活活動強度の指数を乗じて求めることになり, 生活活動強度 1 の場合の指数は 1.3 , 強度 2 は 1.5 , 強度 3 は 1.7 , 強度 4 は 1.9 とされている。 したが って, 第六次改定日本人の栄養所要量の生活活 動強度の指数は, PAL (TEE/BMR) で示され る值と同じ意味を持つことになる。一方，第 5 次 改定日本人の栄養所要量の生活活動強度の指数 $\mathrm{x}$ は, 以下の式に対応して決められていた.

$\mathrm{REA}=\mathrm{BMR}+\mathrm{BMR} \cdot \mathrm{x}+1 / 10 \cdot \mathrm{REA}$

したがって，第五次改定日本人の栄養所要量の 生活活動強度 1 の指数 0.35 は, 第六次改定日本人 の栄盖所要量の生活活動強度の指数 $\mathrm{x}$ (= PAL) に換算すると 1.50 であり，同じく強度 2 は 1.67 , 強度 3 は 1.94 , 強度 4 は 2.22 となる。

\section{文献}

Bangsbo, J. (1993) The physiology of soccer. Hotstrom: Bagsvard, pp.23-34.

Black A.E., Prentice A.M., and Coward W.A. (1986) Use of food quotients to predict respiratory quotients for the doubly labeled water method of measuring energy expenditure. Hum. Nutr. Clin. Nutr. 40C: $381-391$.

Bland, J.M. and Altman, D.G. (1986) Statistical methods for assessing agreement between two methods of clinical measurement. Lancet 1: 8476, 307310.

Caldarone, G., Tranquilli, C., and Giampietro, M. (1990) Assessment of the nutritional state of top level football players. In: Santilli, G. (Ed) Sports Medicine Applied to Football. Istituto di Scienza dello Sport del CONI: Rome, pp. 133-141.

Ebine, N., Feng, J-Y., Homma, M., Saitoh, S., and Jones, P.J.H. (2000) Total energy expenditure of elite synchronized swimmers measured by the doubly labeled water method. Eur. J. Appl. Physiol. 83: $1-6$.

Ebine, N., Rafamantanantsoa, H.H., Nayuki, Y., Yamanaka, K., Tashima, K., Ono, T., Saitoh, S., and Jones, P.J. H. (2002) Measurement of total energy expenditure by the doubly labeled water method in professional soccer players. J. Sports Sci. 20: 391-397.

海老根直之 - 島田美恵子 - 田中宏暁 - 西牟田守 - 吉
武 裕・齊藤㥀一・P.J.H. Jones（2002）二重標識 水法を用いた簡易エネルギー消費量推定法の評 価一生活時間調查法, 心拍数法, 加速度計法につ いて一. 体力科学 $51: 151-164$.

韓国栄養会編（2000）第7次改定韓国人の栄羑勧奨量. 第一出版：ソウル, pp. 112-138.

韓国運動栄盖学会編（2002）運動栄盖学. 賢文社： ソウル, pp. 147-172.

李 明天・金 栄秀 (2002) エリート選手の運動種 目別栄養勧奖量設定. 運動栄養学誌 4:1-20.

厚生省保健医療局健康栄養増進課監修（1994）第五 次改定日本人の栄養所要量. 第一出版：東京.

Maughan, R.J. (1997) Energy and macronutrient intakes of professional football (soccer) players. Br. J. Sports Med. 31: 45-47.

Montoye H.J., Kemper H.C.G., Saris W.H.M., and Washburn R.A. (1996) Measuring Physical Activity and Energy Expenditure. Human Kinetics: Champaign, IL, pp. 17-25.

農村振興庁編（2001）第6次改定食品成分表. 第 1 2 編：ソウル, pp. 38-85.

Racette, S.B., Schoeller, D.A., Luke, A.H., Shay, K., Hnilicka, J., and Kushner, R.F. (1994) Relative dilution spaces of ${ }^{2} \mathrm{H}$ - and ${ }^{18} \mathrm{O}$-labeled water in humans. Am. J. Physiol. 267: E585-E590.

Reilly, T. and Thomas, V. (1979) Estimated daily energy expenditures of professional association footballers. Ergonomics 22: 541-548.

Rico-Sanz, J., Frontera, W.R., Mole, P.A., Rivera, M.A., Rivera-Brown, A., and Meredith, C.N. (1988) Dietary and performance assessment of elite soccer players during a period of intense training. Int. J. Sports Nutr. 8: 230-240.

齊藤愼一・海老根直之・島田美惠子・吉武 裕 （1999）二重標識水法によるエネルギー消費量測定 の原理とその応用. : 生活習慣病対策からトップス ポーツ選手の栄盖処方まで. 栄養学雑誌 57 ： 317-332.

齊藤愼一・海老根直之（2002）スポーツ選手のエネ ルギー所要量策定の基礎研究: 二重標識水法によ るエネルギー消費量測定. 体育の科学 $52 ： 460-$ 466.

Weir J.B.D.V. (1949) New methods for calculating metabolic rate with special reference to protein metabolism. J. Physiol. 109: 1-9.

$\left(\begin{array}{l}\text { 平成 } 15 \text { 年 } 1 \text { 月 } 7 \text { 日受付 } \\ \text { 平成 } 15 \text { 年 } 4 \text { 月 } 26 \text { 日受理 }\end{array}\right)$ 